\title{
National Ethos as a Necessary Factor in Mobilizing for Warfare
}

\section{Eyal Lewin ${ }^{\mathrm{a}}$}

\begin{abstract}
When nations are threatened with violence, the choices they make in order to cope with the challenges of war reflect different alternative possible reactions. They may choose to fight their battles fiercely or they may prefer to surrender and, sometimes, the options lay in-between. The question, therefore, is what makes nations fight and, more importantly, what causes them eventually to win or lose a war. In search of an answer to this riddle, this study examines secondary sources about three historical case studies taken from the first half of the twentieth century that deal with the Republic of Finland, the Kingdom of Norway, and the Soviet Union. It concentrates on the part played by national ethos regarding the manner in which each of them handled their wars in moments of crisis and reveals how national ethos is intertwined with another phenomenon of social psychology that turns it into a crucial factor in the management of international campaigns: enthusiasm for war. A wide historical perspective, however, shows that even though the right kind of national ethos is essential for winning a war, it is far from being enough. Hence national ethos proves, at the end of the day, to be a necessary condition for military victory, but certainly not a sufficient one.
\end{abstract}

\section{Keywords}

National ethos, collective memory, war enthusiasm, war weariness, comparative studies

On May 10, 1940, Germany invaded Belgium and the Netherlands in order to circumvent the Maginot Line in a flanking movement through the thickly wooden Ardennes and, in the course of three weeks, the Wehrmacht managed to completely devastate the French Army.

One of the most decisive battles of this campaign was the Battle of Sedan on May 12, 1940. Sedan was a strategic key point on the east bank of the Meuse River and controlling it would enable the Germans to cross its bridges and roll across the totally undefended French countryside. In spite of its crucial strategic importance, Sedan was captured with practically no resistance at all, and during the next two or three days, the French forces manning the west bank of the Meuse failed to mount any coherent defense.
After the Luftwaffe's bombardment reduced French morale and the French Army was psychologically broken, all the bridges were captured which allowed the Wehrmacht to easily cross the river and penetrate the strategic depths leading to the English Channel without any further meaningful opposition. By June 10, 1940, 100,000 French soldiers were dead and the rest of the French Army had been splintered into small groups, none larger than a battalion and all of them lacking basic vital supplies

aAriel University, Israel

\section{Correspondent Author:}

Eyal Lewin, P. O. Box 789, Mevasseret Zion, Israel 90805

E-mail: lewin1212@gmail.com 
and communications. The victory at Sedan enabled the Wehrmacht to encircle both the strongest French Army and the British Forces in France. In the following battles, the remaining French Army was destroyed and the British units had to evacuate the continent.

Perhaps a clear illustration of the way the French Armies were mauled and rendered themselves impotent emerges from the account of one of Rommel's attacks. The French Fifth Motorized Infantry Division was sent to block Rommel's Panzer division, but the Germans were advancing unexpectedly quickly and Rommel surprised the French vehicles while they were refueling. The Germans were able to fire directly into the neatly lined-up French vehicles and overrun their position completely. Literally overrun in their sleep, the French unit disintegrated into a wave of refugees, and in about 48 hours, Rommel managed to take more than 10,000 prisoners and suffered only 36 losses (Chapman 1968).

A thorough review of the balance of forces between the Wehrmacht that stormed to the west and the French defense forces reveals that the German victory may not necessarily have been predetermined. The French Army of 114 divisions was strengthened by an additional 22 Belgian divisions, 10 Dutch divisions, 11 British divisions, and 10 more divisions of fortress troops that were manning the Maginot Line. All in all, this huge force of 167 divisions was facing the 136 German divisions allocated for the conquest of France so, although they were taken by surprise, the allied forces were hardly outnumbered (Shirer 1969).

As the German advance accelerated the French government fled to Bordeaux where the fate of the Third Republic, in fact, the fate of France, was to be decided upon. By June 10, 1940, the information that the ministers received from the army was that the Wehrmacht's advance was inexorable and unstoppable. Capitulation, however, was not the only possible option and, although it had become impossible to defend Paris, France still had its fleet and its empire intact. Just as Leon Gambetta had left besieged Paris in a hot air balloon during the aftermath of the Franco-Prussian War in order to organize an army to carry on the struggle from the outside, so could the leadership of the Third Republic.

Indeed, Winston Churchill had spoken about making a stand in Brittany and Charles de Gaulle, then the most junior of all the brigadier generals and a newly appointed member of the French war cabinet, had spoken about establishing a base in Algiers. Yet, when on June 16, 1940, Churchill, completely backed by his cabinet, suggested an Anglo-French union, the offer was rejected by the French government. Marshall Weygand, the supreme commander of the French Army tapped Prime Minister Paul Reynaud's telephone lines and then contacted other ministers in a feverish campaign against the plan. Subsequently, after consulting with the ministers, Marshall Philippe Petain, by then, also a new member of the war cabinet called the idea of a union with Great Britain a "fusion with a corpse”, and French Minister Jean Ybarnegaray argued that it would be better for France to become a Nazi province than a British dominion (Churchill 1948: 187; Spears 1954: 298).

It is evident, then, that the high command of the French Army had sunk into defeatism and was determined to capitulate. Having lost all hope, an armistice had become the only option they could think about (Shirer 1969). This defeatism that characterized the French political and military leadership at this time, as mentioned before, crossed all the French social strata and the rank and file of the army. A few days after having left conquered France, Ralph Delhey Paine, the head of the European staff of Life and Time magazines, made the following report to his journal's headquarters (Life, July 8, 1940):

(...) Troops are fed up with the people, the government and officers. People are fed up with troops, officers and the government. The government and officers are apparently looking after their own skins. (...) The officers failed their 
men and their country. We saw hundreds (of officers) among the refugees, evacuating their own wives and families. We noticed the mingling of refugees and defeated troops-soldiers with families, army trucks with civilians. Our definite impression was that there has been little hard fighting since the fall of Paris. We saw virtually no wounded at any time (...).

This testimony corresponds with many others in its description of fleeing troops and regiments abandoning their posts in order to escape the battle, sometimes led by their commanders who had panicked. Some army units dissolved without being attacked and others faded away at the mere threat of Germans with the troops, ultimately joining the increasing numbers of refugees who formed long columns that blocked the roads and interfered with military supplies of food and petrol (Shirer 1969; Waterfield 1940).

How come a major European power like France was simply unwilling to properly defend itself? Outnumbering the German 2,445 panzer force with their 3,383 tanks, the French could have isolated the Wehrmacht's motorized forces from the slowly advancing infantry and, more importantly, from its crucial logistic facilities thus turning the Blitzkrieg into a deadly trap if they had only fought (Bartov 1991). Why, then, did they just practically surrender? What is the explanation for a nation's decision to give up its assets and chose submission, where rape, robbery, torture, and humiliation are expected, over struggle? What, conversely, drove other nations in similar circumstances to resist, at times against all odds, and to struggle? What is it that urges nations to fight their way to survival and victory? A partial answer, suggested in this paper, can be found in the notion of national ethos.

\section{THEORETICAL FOUNDATIONS}

The national ethos of a country derives from the array of the shared particularistic values and traditions that form a people's envisaged image of its future and past. The ethos integrates the community into feeling a common mutual destiny and forms the foundations of its unique identity as a distinctive social group. The integrative ethos is also the moral source for the national community's informal social controls; it enforces commitments upon society and drives its members into a largely voluntary social order. Thus, the ethos of a nation, in fact, is one of the most important key factors for a people's ability to unite into a cohesive society (Etzioni 2009).

The use of ethos in political science goes back to the German romanticism of the late eighteenth century with philosopher Johann Gottfried Herder introducing the term Zeitgeist, which translates into "the spirit of the age”. Inspired by philosopher Friedrich Hegel's concept of mind and moral fiber, Herder spoke of the cultural, ethical, and political climate in which a nation evolves and crystallizes (Barnard 2003). These ideas suggest that there is a strong association between the ethos and representations/significance of a far history that the nation claims for itself. As some scholars claim, the features of a community originate during those historical stages when the mental maps of the people, their prevailing culture, norms, and ideas are cultivated (Rothstein 2000). This notion also corresponds with the writings of sociologist Maurice Halbwachs who is considered to have been the first to use the concept of collective memory. Inspired by the ideas of philosopher Henri Bergson, who had distinguished between the memory of a specific event and the memory of enduring attitudes, and on the socio-cultural accounts of sociologist Emile Durkheim who had written about the manner in which Australian Aborigines had preserved sacred values and rituals in their communities, Halbwachs wrote of a group memory that was shared, passed on, and constructed by the members of such a social group. Rejecting Freudian and other purely psychological approaches, Halbwachs claimed that it was impossible for an individual to remember in any coherent and persistent 
fashion outside his group contexts and that memories were not preserved in one's brain or in one's mind but, rather, were external recollections controlled and constructed by the group. According to Halbwachs and other advocates of collective memory who have followed him, such as historians Marc Bloch and Aby Warburg, a social group's common recollection is a contested ideological terrain, where different actors try to establish their particular interpretation of the past as the only manner in which their particular group should comprehend its history. Society's collective memory is an ongoing process that unites the group under the ideological perceptions and under the common ethics that are derived from its told and retold history (Durkheim [1912] 1995; Halbwachs [1951] 1992; Rothstein 2000; Russell 2007).

Brooding over a century of bloodshed, the late twentieth century scholars have added critical insights to the comprehension of collective memory, particularly in its national contexts. Statist ideologies, some of them claim, involve a manipulation of space and time in order to legitimate a monopoly of administrative control. National history, according to this attitude, is no more than a presentation of false unity designed through an elite's conquest of historical awareness. These scholars also point out how national states all over the world exploit professional historical research and shift their peoples' center of collective memory from, for example, the temple and its priests to the university and its professors, from a religious set of myths to a political one relying on a subjective interpretation of history at best (Duara 1995; Levi-Strauss 1979; Smith 1986).

Whether judging the phenomenon as either a positive or destructive factor of our society, it seems that decades after Halbwachs, scholars have examined and reexamined his terminology, and have once and again arrived at the same concept. The basic understandings are that a social memory shapes images of the past and, by doing so, draws the lines of political cultural profiles (Fentress and Wickham 1992;
Olick and Levy 1997).

In its national context, the idea of a collective memory resides deep in international studies theorist Benedict Anderson's comprehension of the nation as an imagined community. The national identity, according to Anderson, has a symbolic and constructed nature and, by utilizing the communicative media, it is capable of reaching dispersed populations (Anderson 1983). The collective identity of a nation as a unique combination of a public that shares mutual values and beliefs lies in its common narratives, that is-in its constructed collective memory and in the united role that its members believe that fate had destined for them in this world. This is the national ethos, and it contains the foundations of the collective identity through the sense of a certain duty that the nation is bound to fulfill and through a set of common goals that the people as a united entity have been ordained to achieve.

The notion of national ethos is intertwined with another phenomenon that is worthwhile mentioning particularly in the context of war: war enthusiasm. The prevailing scholarly concept views war enthusiasm as the reflection of a people's will to sustain any struggle. According to this observation, it is not the physical loss and destruction that determines a nation's decision to continue a struggle or to surrender, but simply its spiritual willpower. As long as a government and its citizens are motivated to continue, the struggle will not cease (House 2008). War enthusiasm, for example, was recorded when, in 1915, after the outbreak of World War I over one million men enlisted in the British Army. This was a recruiting boom that took place at a rate that history had never known before and it reveals an enthusiasm that possessed all the layers of British society (Silbey 2005; Simkins 1998).

The story of the British public is certainly not exceptional since other European nations also seem to have greeted the coming Great War with unbounded 
energy and passionate fervor, lending this chapter in history the name "August days", referring to the particular month when war broke out. War enthusiasm was everywhere, inside, and even outside the continent, infecting the German people (Verhey 2000), the French (Becker 1986), the Irish (Browman 2003), the Welsh (Gregory 2008), and even the Australians - so far away from Europe (Scott 1989).

The mirror-image of war enthusiasm is a phenomenon called "war weariness", analyzed as a public tendency to avoid any violent international conflict. It is often asserted that the harder the war experience is the higher the chances are that both the decision makers, as well as their followers, will abhor any interstate conflict (Mueller 1989; Richardson 1960; Toynbee 1954). Allthough it does make sense to connect war weariness with the experience of defeat, in defeated countries the desire for revenge might overcome any war fatigue and might, in fact, even lead to mounting war enthusiasm (Most and Starr 1980; Organski and Kugler 1977).

Indeed, when the case of the demise of the Third French Republic is analyzed, historians adopt an attitude based on the concept of la décadence (the decadence), according to which the French defeat resulted from a lack of willpower among French society and from the moral rot, weakness, and cowardice of its leaders. Perhaps the first outstanding representative of this concept is historian Marc Bloch, who as a warrior in the resistance, was caught and tortured to death by the Nazis in 1944. Almost in real time, Bloch completed his book Strange Defeat which, in its very title, indicated the point of view of the study that was published after his death and blamed the French social and political culture for the sudden and total military defeat (Bloch 1968).

The la décadence point of view, then, could provide a solution to the mystery of why France had collapsed and that is the national ethos-the mental state of the French people and their leadership. This national ethos can be traced all the way back to the very formation of the Third French Republic which took place under the circumstances of military defeat and social collapse. It was no coincidence, as will be presently shown, that the first event that marked the establishment of the republic was the brutal oppression of the Paris Commune in 1870.

The commune was an autonomous, socialist, and political structure formed by the working class in Paris after France was defeated in the Franco-Prussian War. It was created when Paris was under siege by its German enemies which caused widespread social discontent as a result of the military failures, food shortages, the socioeconomic gaps and the devastation caused by the Prussian bombardment of the capital. Hundreds of thousands of Parisians were members of the National Guard, an armed militia, democratically organized by elected officers from each district who took power in order to defend Paris in the event that the Germans would attempt entering it. Men and women moved hundreds of cannons to the heights of Monmartre where they intended, as a last stand, to shoot at the Germans entering Paris.

Unlike the population of Paris, the provisional national government, which was moving from Versailles to Bordeaux, was less anxious to fight the Germans and more concerned about the socialist activists who were gaining power inside the city. Adolphe Thiers, the head of this government, sent French Army Troops to disarm the forces of the National Guard, but the soldiers who arrived in Paris joined the local residents and soon the Paris Commune was to become, not only an alternative to the national government, but also a democratically organized one, led by workers, doctors, journalists, and political activists.

The Thiers government ultimately decided to act resolutely and, aided by the Prussian conquerors of France who released French prisoners of war for this purpose, attacked Paris. Fighting took place in the streets with government troops slaughtering civilians and summary executions a common occurrence and, 
in the course of one week, some 40,000 French citizens were killed by their own government's army (Cobban 1990; Wright 1995). The fundamental national ethos, the historical legacy of the newly established republic was, it seems one where, even when the enemy was at the gates of the capital, the quest for domestic political power formed national cleavages that took priority over any patriotic struggle.

\section{METHODOLOGY}

In comparative social studies, when systems constitute the original level of analysis and within-system variations are explained in terms of systemic aspects such as the national ethos, a "most similar systems" research design proves to be the best strategy. The basic assumption of this methodological approach is that systems that are as similar as possible with respect to as many features as possible constitute the optimal samples for comparative inquiry (Przeworski and Teune 2000). In search of parallel case studies, geographic and timing considerations have led this research to focus on the landscape of World War II. As an issue that falls within the general methodological definition of a small-N study (Lieberson 1991), this project examines three case studies of countries that experienced both domestic and international hazardous situations at the beginning of the Twentieth century: (1) the Republic of Finland during its First Winter War; (2) the Kingdom of Norway and its 1940 submission; and (3) the Soviet Union and the 1941 Battle for Moscow.

These cases differ in their history, geopolitics, culture, and numerous political psychological factors, making each of them entirely unique and thus incomparable with any other case. Yet the nations involved lived through the same regional geopolitical environment of the Europe of the first half of the Twentieth century and, by being located in the same continent and exposed to the same threats and opportunities, these different countries have, in a way, been situated in a historic laboratory which allows us to observe how different variations of national ethos can act in similar settings.

\section{FINDINGS FROM THE CASE STUDY OF THE REPUBLIC OF FINLAND}

The Republic of Finland evolved as the result of a traumatic civil war, considered to be the bloodiest in modern European history, in which a large portion of the population was killed. In spite of the decisive outcome, with the clear victory of the non-communists, the country was left torn apart with divisions that would last many years to come (Paasivirta 1981; Raun 1984). On the other hand, almost as soon as the fighting between the two groups ceased, a process of political negotiations took place with moderate political parties constantly pushing for reconciliation. The democratic nature of the new state enabled the Finnish society to lessen the severity of the ideological and class conflicts and the political process of legislation and cooperation made the diminishment of the social gaps possible.

International politics during the 1930s also added to the reunification of Finnish society as the August 23, 1939, Molotov-Ribbentrop Pact, and its immediate implementation with the conquest of Poland, came as a blow to both rightists and leftists. The former quickly realized how Nazi aggression was something that could quite easily have been turned against Finland, and the latter understood that the proximity of Soviet Russia provided no guarantee for peace or for any world balance that would be anti-Nazi. Moderate Finns from both political persuasions were also disappointed with the impotence of the League of Nations that could do nothing to stop world aggression, and the incapacity of the whole international community, in particular the Western powers, to defend the weak and non-violent nations.

Thus, in the course of two decades, on the eve of a war against a world empire, the Finnish nation 
completed the process of healing the scars of the Civil War that they had experienced, and reunited on the common ground of their national beliefs. National unity, the rallying call in social circles in all fields of life in the Finland of 1939, was described by the specific Finnish expression Talvisodan henki which stood for "spirit of the Winter War" (Kirby 1978; Manninen 1978; Siaroff 1999).

On November 30, 1939, Soviet Forces launched a massive attack on Finland, Russia's small neighbor that, at the time, had a population of no more than three million people. The odds were entirely against the vastly outnumbered and poorly equipped Finnish army, but its courageous resistance led the Finns to win their freedom through a one-hundred-day struggle known as the First Winter War. On March 12, 1940, the Peace of Moscow Treaty was signed, turning Finland into the only country that had fought Stalin and survived as a free and independent nation (Siaroff 1999).

Finnish independence dates back to the beginning of the nineteenth century, when it was conquered by the Russians and taken from the Kingdom of Sweden to act as a buffer state that would protect the Tsars' capital of Saint Petersburg. Autonomy in Finland continued, but the policy of Russification that whose purpose was to assimilate the Finns, ruined relations between the two countries, and the Finnish demands for self-determination and disengagement from Russia prevailed. The 1917 Civil War in the newly created Soviet Union was an opportunity for the Finns and the Senate of Finland declared its independence, a course of action that the Bolshevik government at the time was too weak to effectively oppose (Luostarinen 1989).

Following their invasion of Poland in September 1939, the Soviets turned their attention north to Finland and demanded that the Finns totally retreat from the Leningrad zone and move their international border some 25 kilometers back into Finish territory. This demand was flatly refused and the Soviets reacted by massing an army of about a million soldiers along their border with Finland (Spring 1986).

Four days before they attacked the Soviets faked a Finnish shelling of Mainila, a Russian town situated out of the Finnish artillery's range. This phony incident functioned as the false causus belli for the Soviets to launch a war against their small neighbor and 450,000 Red Army troops crossed the border to engage the Finnish Army which initially numbered only 180,000 soldiers. The Finnish army was not only outnumbered but also technologically inferior and lacked basic supplies of ammunition and clothes. In response to Russia's 3,800 planes, the Finnish Air Force had no more than 130 aircraft out of which merely 46 were fighters. A greater problem than the scarce human-resources and the lack of guns and machinery was the lack of materials because of the German blockade on Finnish ports which only allowed the importation of small quantities of weapons and only enough ammunition to last no more than a month or two. This meant that the Finnish Army experienced constant shortages and often could not afford to fire their weapons leaving field commanders having to think twice before they shot a bomb or threw a grenade and meting out a small number of bullets per soldier. The artillery softening of enemy targets, for instance, was in most cases a luxury they could not afford.

The Finnish Forces manned a defense line along the Karelian Isthmus, a stretch of land on the Gulf of Finland and Lake Lagoda which formed a buffer zone and allowed the Finns to combat the invading forces with some of the heaviest fighting of the conflict. This war zone, the Mannerheim Line, named after their leader, was originally a row of guarding posts built in the 1920s and partly extended a decade later. This was no Maginot line having barely one reinforced concrete bunker per kilometer and its effectiveness, from the very beginning, was based on the defenders' stubbornness. Indeed, when the Finnish soldiers first encountered the Russian attacks, it was noted that 
their role as a defensive force was marked by bravery as they managed to delay, and to temporarily halt, the invading forces. They, however, suffered from a clear handicap in that they had neither effective protection against the Soviet's heavy guns nor any anti-tank weaponry to fight the advancing Soviet tanks. In order to cope with the overwhelming attacking force of the Red Army, the Finnish leadership had to come up with some innovative tactics, in particular those similar to guerrilla warfare.

The Russians attacked in regimental force, a strategy fit for the large number of soldiers that they had at their disposal and thus often became easy targets for the Finnish snipers. Dressed in dark uniforms, the Red Army soldiers were easily identified and a single Finnish gunner could hide in the snow and, from a long distance away, kill hundreds of them moving toward the combat zone. Fighting on their home ground in its full sense, the Finns were very familiar with the local topography and, unlike their enemy, used white camouflage and moved rapidly around using skis. The casualties that the Finnish troops inflicted on the Red Army in the fighting zone were staggering because their tactics made it possible for them to function as a fast-moving light infantry that would swiftly encircle isolated enemy units and destroy them on the spot.

Having hardly any tanks of their own, the Finns specialized in alternative tactics for hunting down the Soviet tanks. For example, a four-man team would use wooden logs to jam the tracks of a tank or its bogie wheels, and, once the tank was immobilized, they would use Molotov Cocktails or improvised satchel charges to blow up its fuel container. Over 2,000 Russian tanks were annihilated this way and, after a month's fighting, the whole Soviet attack was halted. This guerrilla warfare was later known as the Motti tactic, Motti being the Finnish word for entrapment. Using such a strategy, the Finns maneuvered the superior enemy forces into inferior positions where the Russians could easily be defeated. Since the mechanized units of the Red Army were effectively restricted to the long and narrow roads that crossed Finland's forests and could not move in any other way than forwards or backwards, once they were committed to a certain path their routes were turned by small Finnish units into traps. Finnish troops cut down trees and blocked the road and when the Soviet armored columns arrived they emerged from the forest gliding on their skis and broke the large Russian units into smaller sections. The smaller pockets of enemy troops who, by now, had lost most of their relative advantage were trapped and had to face Finnish forces on all sides. For many of the encircled Soviet troops, fighting the Finns who had ambushed them was no less than a nightmare. Once trapped, they stood very little chance of fighting off their predators and, if they refused to fight, they would be shot by their commissars. Surrender was not really an option as Soviet propaganda had taught them that the Finns would brutally torture them and sneaking into the forest meant dying from frost and starvation. It was now, all of a sudden, their turn to fight for survival.

By using the ability of their light troops to travel over rough ground quickly and trap enemy units on the roads, the heavily outnumbered but mobile Finnish forces found the key to overwhelm the enormous Red Army that had invaded their country. The Soviet advance was consequently stopped at the Mannerheim Line as their troops suffered from low morale and supply shortages. The Motti strategy managed to effectively challenge the invading forces and enabled the Finns not only to kill or imprison their enemies, but also to rearm their forces; Finnish troops captured dozens of tanks, cannons, anti-tank guns, hundreds of trucks, thousands of horses, thousands of rifles and, above all, the ammunition and medical supplies which they desperately needed. The strategic Finnish victory reached one of its peaks when on January 5, 1940, at the Battle of Suomussalmi, three Finnish regiments managed to completely destroy a soviet force of two divisions and a tank brigade. On the Soviet side, over 
17,500 soldiers were killed while the Finns only suffered 250 casualties.

Time, however, was running out for the Finnish defense forces and, in January 1940, the Soviets began increasing artillery and aerial bombardments in order to soften the Finnish defenses. Because of ammunition shortages, the Finnish artillery could not properly respond to the Soviet's massive shelling which forced them to take shelter inside their fortifications during daylight and repair the damage caused at night. This new phase of attrition, however, caused them to lose over 3,000 troops within a fortnight and the ongoing trench war was also wearing down the defenders. In addition to tying up the Finnish forces by bombarding them massively, the Red Army adapted its strategy to the Finnish warfare tactics and launched small infantry assaults where one or two companies harassed the defenses, killed Finish troops, and returned to the Soviet lines. In contrast to their previous tactics, the Soviets now changed their tanks and the troops' uniforms to white camouflage and the tanks now advanced in smaller numbers with large formations of infantry soldiers protecting them.

By early February 1940, after 10 days of suppressive fire and fierce combat, the Finnish resistance started to weaken as the men suffered from fatigue, at times falling asleep in the trenches even when the enemy tanks were rolling toward their positions and shells were falling everywhere around them. Finally, after deploying 460,000 troops, 3,000 tanks, 3,350 artillery pieces, and 1,300 aircraft, the Red Army managed to overcome the tiny Finnish army and made a breakthrough in the Mannerheim Line. One after another, the defenders' strongholds crumbled under the Soviet assaults and the Finns were left with no choice other than to retreat and take up new defense positions.

Yet even when their frontier had collapsed and they were close to breaking point the Finns refused to give in. With the Russians on the outskirts of Viipuri, Finland's second-largest city, a Finnish party was dispatched to Stockholm to begin peace negotiations with the Soviets. As the talks started, fighting continued intensively and hundreds of Finnish soldiers were killed every day with some Finnish divisions practically losing their chain of command, but the orders remained to keep struggling at all times and at all costs. Precisely because the ceasefire was being negotiated, it was all the more important for the Finns to create the impression that they would never give up, but it was also essential that the agreement reached in Stockholm would be one of fair negotiations and not one of total surrender. The battle now had become a struggle for the credibility of faking a force that would be seen as being capable of waging a continuous war with the Russian invader and in this game of poker being played by the Finnish military leadership, they had practically run out of playing cards.

By the time the treaty was achieved, Finnish casualties numbered about 26,600 dead and almost 40,000 wounded. The Russians, on the other hand, suffered a death toll of over 126,000 soldiers and 265,000 wounded, and lost 2,270 tanks and armored cars. Spring was approaching, and unaware of the total exhaustion of the Finns, the Soviets feared having to face prolonged guerilla warfare in the forests and the possibility of a Franco-British intervention. This whole situation, in which a tiny country had proved to have been an even match to the Red Army, caused Moscow an embarrassment that made its leadership feel it had to put an end to it. Consequently, on March 12, 1940, the Moscow Peace Treaty was signed. According to the treaty, Finland ceded around $11 \%$ of its land, consisting of about $30 \%$ of its industrialized zones and the large city of Viipuri (Anderson 1954; Chew 2002; Edwards 2008; Engle and Paananen 1973; Karsh 1986; Screen 2001; Trotter 1991).

Despite the terrible losses, however, and seen from a historical perspective, one cannot ignore the fact that the Finns retained their complete sovereignty. Against the large military operations conducted by their enemies, they demonstrated great spiritual willpower, 
brave patriotism, and flexible strategies carried out by courageous forces even when outnumbered and fighting against all odds. Theirs was the vivid proof that, even without international aid, a decisive nation, tiny as it may be, can preserve its independence and that, even when a petite state is threatened by an aggressive empire, it can still preserve its freedom.

The case of the Finnish national ethos is a unique one. Reflecting the willpower that the Finnish people perceive themselves as possessing, their language holds a special, practically untranslatable, term which explains the culturally inherent virtue of the strength of the soul. The Finnish word sisu relates to an intrinsic Finnish quality that stands for determination, insistence, and perseverance and describes the courageous ability to sustain an action even when, on the face of it, there is no chance other than to fail. Perhaps the closest English literal equivalent would be "having guts", but it is important to notice that sisu is not only about momentary bravery but rather about the capacity to endure things over a long period of time and thus demonstrate the force of the spirit to cope with the challenges of reality. The virtue of sisu, then, is the ethos that directs one to take a course of action even when its direction seems hopeless, to stick to this course of action in the face of repeated failure and to refuse to surrender even when all seems to be lost. These characteristics of the Finnish cultural trait of sisu form an unbreakable national ethos (Goss 2009; Halmesvirta 2009).

\section{FINDINGS FROM THE CASE STUDY OF THE KINGDOM OF NORWAY}

Norway became an independent constitutional monarchy in 1905 following its departure from a century-long union with Sweden. Since both countries decided to end their union peacefully, this is remembered as one of history's rare occasions when a country's independence was acquired by diplomacy and peaceful arrangements rather than by blood and sacrifice. The democratic nature of the new country was consistent with its birth through the friendly divorce that took place between the two sister-monarchies that also decided that no fortifications would be erected along their borders. In fact, democratic social legislation has typified Norway from its very first years with direct election for members of the Storting (the Norwegian parliament), proportional representation for minorities, and the establishment of women's full voting rights.

During World War I, Norway remained neutral but, as a result of the unrestricted German submarine warfare, half of the Norwegian mercantile marine fleet was sunk and about 2,000 sailors were killed. To a large extent this sacrifice had the effect of changing the Norwegian orientation and, despite the fact that, for generations, Norway had closer cultural ties with Germany than with Britain, now a common fate moved the Norwegians closer to their western neighbors.

The major achievement that Norway strove to gain from the tragedy of World War I was the development of a new international system in which a small state could be effective in the management of world affairs. Long before the great powers adopted it, Norway had already presented a plan for the League of Nations. When the overarching international institute was finally established, it came to be dominated for almost its entire duration by the Norwegian delegates.

Norwegian foreign policy has, in general, been practiced according to an idealistic democratic attitude. When a dispute with Denmark over East Greenland, for instance, threatened not only Norwegian national hegemony, but also the basic profits of Norwegian whalers and hunters, the matter was brought to the international court at Hague. The international court then decided in favor of Denmark and despite the judgment being against their needs and interests and considered to be an unfair judgment, the Norwegians accepted it. Theirs was the national ethos of law-abiding people and this spirit also prevailed in their foreign policy. 
The pacifist attitude was anchored so deeply in the Norwegians' confidence in international cooperation that it led Norway's major politicians, throughout almost the entire political spectrum, to believe that military preparedness for a small state was unnecessary. Even when other countries experienced the hazards of warfare, the firm belief of the Norwegian leadership was that their country's neutrality would be respected in any future war (Derry 1957; Derry 1973; Larsen 1948).

The ethos of the Norwegian people was, perhaps, the ultimate ethos of pacifism. One illustration of Norway's role among the nations can be demonstrated through the procedures of bestowing the Nobel Prizes. Alfred Nobel was a Swedish chemist, and he established the prizes when the two monarchies were still united, but it became quite natural, after the peaceful divorce, for all the prizes to continue to be awarded in Stockholm while the Nobel Prize for peace would be awarded in Oslo. The Nobel Prize laureates for sciences are chosen by Swedish academic organizations, but the laureates for peace are decided upon by a Norwegian committee.

An ethos, however, needs its myths and its heroes, and the new Norwegian tradition established the champions of its pacifist legacy in the adventurous scientific frontiers that excited the world at the beginning of the twentieth century. Fridtjof Nansen was just one among a group of leading Norwegian explorers who devoted their lives to the geographical research of the icy zones of the North and South Poles. Starting with Nicolai Hansen, Norwegian explorers have been involved in many expeditions, in most cases alongside researchers from other nations, and have demonstrated heroic enthusiasm, often risking their lives and sometimes even losing them, for the sake of completing the missions of reaching new frontiers. The most well-known among them was Roald Amundsen, who was the first person to reach both poles and the discoverer of the Northwest Passage, the sea route through the Arctic Ocean that connects the Atlantic and the Pacific seas along the northern coast of North America. Very typical of Norwegian national pride and their perception, of themselves as being one nation amongst others, Amundsen was eventually killed when, in 1928, on a rescue mission in search of a lost Italian crew his plane crashed into the sea (Huntford 1999).

At midnight on April 9, 1940, 15,000 German soldiers landed in the ports of Norway. The Norwegians' coastal defenses proved to be useless, because their armament was meager and they were psychologically unprepared for the brutally abrupt transition from peace to war. In the course of several hours, most of the ports were taken and the most important Norwegian ships were torpedoed with hundreds of sailors losing their lives. A mobilization order was issued early in the morning but was inadequately handled and, by the time the ministries tried to implement it, many of the mobilization centers, which contained the equipment for the army, and all the main ports, with their more readily deployed manpower, had already fallen into enemy hands. In practice, only a small number of the people was involved in the struggle against the German invader since fighting took place mainly in areas that had not been densely populated and the Norwegian farmers, for instance, only heard about such events mostly in the news. The army's full mobilization strength was 100,000 soldiers, but only $50 \%$ of them were in service and less than $25 \%$ were available at any time during the campaign. No wonder, then, that Norwegian casualties hardly exceeded 2,000 soldiers and civilians killed in action. The Norwegian people, for all practical purposes, failed to participate in the defense of their country.

The most important move made by the Germans on the first day of the assault was gaining air supremacy by annihilating the Norwegian air force and taking over the airports. This put the Luftwaffe in the decisive position that would eventually determine the result of the whole confrontation. The 
Norwegians' only hope now lay with the British and French forces that would presumably drive Germany out of their country, but the Allied aid soon proved to be a broken reed and, in order to avoid capitulation, the only option left for the Norwegian king and his government was to join the retreating Western forces and leave the country. Thus, on June 10, 1940, the Kingdom of Norway finally lost its independence and ceased to exist (Derry 1973; Weinberg 1994).

\section{FINDINGS FROM THE CASE STUDY OF THE SOVIET UNION}

At dawn on June 22, 1941, the largest military assault in human history took place when, on a wide front stretching from the Baltic Sea to the Red Sea, more than three million Wehrmacht troops, reinforced by some 500,000 Romanian, Hungarian, Slovakian, Croatian, and Italian troops, attacked the Soviet Union. The enormous number of ground forces was accompanied by a massive air strike in which the Luftwaffe smashed forward-deployed Soviet air squadrons, in most cases before they even had the chance to leave the ground and, during the following weeks, nearly 4,000 Soviet aircrafts were destroyed. Implementing their winning Blitzkrieg doctrine, the German Panzers encircled hundreds of thousands of Soviet troops and inflicted a crucial blow to the Red Army. The advance along the entire front was so quick that, within several weeks, Byelorussia, Lithuania, Latvia, and Estonia were under German occupation. Three million Russian prisoners of war (POWs) were captured, roughly $40 \%$ of the Russian population was held under German conquest and about $50 \%$ of Soviet material assets and its industrial and agricultural resources were in German hands.

The retreat of the Red Army was conducted, under Joseph Stalin's orders, using a scorched earth policy. Destruction battalions were immediately formed in the front-line zones whose duty was to burn down public buildings and schools and to demolish towns and villages. The Soviet command, however, went further than just applying a scorched earth policy and, as the army was constantly losing hold of the western regions, entire factories were taken apart, packed onto flat railroad wagons and evacuated to the faraway east areas of Central Asia in order to be re-constructed there. In this way, more than 1,000 large war plants were transported to the Volga region, to the Urals, to Siberia, and to Kazakhstan from Ukraine and, within four months, the factories were not only reconstructed but were also working at full capacity. Thousands of industrial workers were evacuated together with their dismantled plants and had to endure working 14 hours a day, food shortages and living in mud huts and tents in their new locations.

Despite the Red Army's retreat, the Soviet citizens fought fiercely against the Wehrmacht engaging in raids, sabotaging valuable resources, disrupting road and telecommunications, assassinating German personnel and gathering intelligence. Soviet recruitment stations were flooded with volunteers and entire divisions of popular militias were established. Special guard units were created in order to confront German paratroops and labor battalions were formed to build new lines of fortifications. The Soviet partisan movement was, in fact, a people's army of irregulars, fighting behind enemy lines. These insurgents included men, women and Komsomol (Communist Youth Movement) teenagers, as well as Red Army officers and soldiers whose units had been destroyed in the first stages of the Barbarossa attack. By the end of 1941, more than 90,000 partisans were operating in German occupied territories (Heller and Nekrich 1986; Slepyan 2006).

A typical story is reflected in the chronicles of the Tula resistance that took place between October 24 and December 5, 1941. Tula was a fortified city that became the target of the German offensive on the road to Moscow. The mechanics in the factories of Tula remained at their posts day and night, repairing the shattered tanks and ruined field guns that been hauled 
there straight from the combat zones. Some of them were wounded and nurses were called in to attend to them in the workshops, but the effort continued and the machines did not stop working. Anyone who could hold a gun, including 15-year old and 16-year old boys and girls, manned the trenches and barricades of Tula. The young ones joined guerrilla bands where they learned to throw hand grenades and kerosene bottles at tanks and sneaked behind enemy lines to scout for information about the disposition of German troops. In spite of trench mortar fire and bullets, girls crawled toward wounded men and carried them on their backs from the battlefield. In face of the German advance, and out of fear for the fate of the injured soldiers, in some of the villages, women and girls hid the wounded in dugouts, in the woods, in cellars, and in haystacks (Hindus 1943).

In spite of the German's rapid advance, the Soviet resistance along the whole front, particularly in Smolensk, slowed down the attack and the central group of the Wehrmacht was ordered to halt its race toward Moscow in order to reinforce the southern forces fighting in Ukraine. Stopping the advance toward Moscow, Hitler's personal decision made against his generals' advice, proved to be one of the great tactical mistakes of World War II and was only renewed at the end of September 1941. Alas, the Germans were now controlling larger areas where the Wehrmacht had to be deployed and fewer forces could therefore be dedicated to further conquest. On top of this, the surprise factor that had made many of the earlier accomplishments possible was now gone. The advance did recommence, only this time, the Soviet resistance managed to slow down the German efforts and it was only in mid-November 1941 that the Wehrmacht forces reached the defense lines surrounding Moscow 30 kilometers from the Kremlin. This was going to be as near as they would ever get.

During the previous four months of autumn, Stalin had been creating reserve forces and fresh, well-equipped Soviet forces had been brought from
Siberia and from the Far East to the Moscow frontline. On December 5, 1941, supported by new tanks and backed by Katyusha rockets, that had an enormous psychological shock effect, the Soviet forces launched their counter-attack. The tough Russian weather caught the Wehrmacht totally unprepared for a winter war and poorly equipped to cope with the frost and snow. Even before the temperature fell far below zero, rain and mud hindered German mobility and played havoc with essential logistics. When the weather became worse, the German troops, who were caught without proper clothing, were freezing as was the oil and fuel in the vehicles and icy grease had to be removed from every loaded shell. By now, the Wehrmacht was practically worn out and had suffered 155,000 dead soldiers, the loss of 800 tanks and 300 heavy guns and, more importantly, it had no reserves with which to continue an offensive. In less than two months, by January 27, 1942, the Red Army drove the exhausted Germans some 100 kilometers away from the Soviet capital. Moscow, although still relatively close to the frontline until late 1943, was relieved. The cost of victory had been awful and historical estimates vary, but the more moderate ones largely refer to approximately 650,000 Soviet casualties and around 300,000 Germans killed. It was, undoubtedly, one of the most lethal battles in human history.

The battle of Moscow did not win the war for the Russians and there were to be further defeats awaiting the Red Army. Indeed, it would take over three more years before Soviet forces would finally reach Hitler's bunker in Berlin but, nevertheless, the battle over Moscow was both a turning point in the east and a clear indication that the Soviet Union was to prove unbeatable. The results of the Battle of Moscow completely eliminated the danger of a German invasion of Britain, gave renewed strength to resistance all over Europe and marked the beginning of the end for the Third Reich (Bergstrom 2007; Glantz 2001; Glanz and House 1995; Heller and Nekrich 1986; Service 2005; Treadgold 1995; 
Rotundo 1986).

The Russian national ethos played an important role in the Soviet victory. Already in his February 1931 speech to some leading industrial managers, Stalin quoted the nineteenth century Russian poet Nikolay Nekrasov and introduced the national personification of the country by using the expression "Mother Russia", Rossiya-Matushka, which would, from then on, be in common use particularly with the start of the war. It was only natural, then, that, when the war started, Stalin pleaded with his soldiers to fight, not for Communism, but for Mother Russia. The very morning after the Nazi invasion, on June 23, 1941, the term "the Great Patriotic War" was imprinted by an article in the Soviet newspaper Pravda in which the reference to the Patriotic War of 1812 was clear. Once again a large army had invaded Russia and, once again, it had retreated in defeat. This seemed to have been the leading theme which seemed to say that history has its ways, and eventually, the Russian people would prevail and the invaders would be annihilated. A 1941 war poster showed a portrait of Mikhail Kutuzov, the much-admired Russian general whose brilliant command had enabled Napoleon to storm into Russia just to be beaten at Borodino and then to be pushed all the way out of the country with his Grande Armée annihilated. Under Kutuzov's new portrait there was a quotation from Stalin which read (Hindus 1943: 134): "Let the valorous example of our great ancestors inspire you in this war”.

In the Russia of World War II, a new recognition of the legendary national ethos emerged and the Soviet Union entered into a process of rediscovering its Russian origins, re-interpreting past events, and reinventing its collective memory, but providing it with fresh meanings and a spanking new sense of glory (Hindus 1943; Treadgold 1995; Service 2005).

\section{CONCLUSIONS}

According to Carl von Clausewitz, war is an act of force intended to compel a nation's enemy to do its will. War is therefore a struggle for power, whether it is to impose one nation's desire on other social groups or to resist such impositions (Clausewitz [1832] 1982). This struggle for power is an intrinsic element that exists in the relations between states, hence the account made of hostile campaigns has always been the crux of international politics. States seek advantages over other states in order to ensure national survival and provide a better life for the leading social forces of their countries and, consequently, when these advantages can be satisfactorily acquired through the practice of war-international violence is bound to take place. In the future, therefore, violence will probably continue to be a significant factor used to settle disputes between nations. Even if we assume that reason and restraint can prevail, even if we adopt the thought that generosity/ magnanimity can replace hatred and envy, sometimes all it takes is a single eccentric member of the community to violate the norms and violence can finally emerge. Hence even the most optimistic pacifists can hardly deny that war does not exist only in human history but that, to one extent or another, it will remain an integral part of any future social life. It seems that the vitality of Sun Tzu's 2,500-year old claim that war is crucial to the country because it is where the state takes a road to either survival or ruin will not fade away in any forthcoming international scenario (House 2008; Vital 1971).

It is for this reason that the question of who wins wars and the quest for the factors that lead to military victory are not merely there for the purpose of scientific curiosity. These are realistic issues that decision-makers have to be aware of as part of their practice as leaders.

In order to examine the role of national ethos as a key factor of a country, a comparative research was constructed, which on three case studies of political participants in war during the late 1930s and early 1940s: (1) the Republic of Finland during its First 
Winter War; (2) the Kingdom of Norway and its submission to Nazi Germany; and (3) the Soviet Union and the Battle of Moscow.

The results indicate that both Finland and Russia, in two consecutive wars, were fuelled by an inspirational national ethos that turned an expected loss into an impressive victory. In the Finish case, it was the notion of sisu, deeply imprinted in their culture that drove them to struggle against a force so much mightier than them. In the case of the Soviet Union, it was the collective memory of the Great War that inspired the Great Patriotic War where Mother Russia's fate was at stake. In the case of the Kingdom of Norway, however, where a national ethos of peace was constructed, the country was simply unfit to fight its wars. With national heroes who were peace-abiding diplomats and adventurous world explorers, the Norwegians would do anything but fight. Obedient to the international court in Hague, even when it ruled against them and deprived them of East Greenland, it is clear that Norwegian national assets or interests were second in priority to peace. With no appropriate national ethos based on the collective memory of historic wars, it was almost inevitable that they would surrender to the Germans who invaded their country.

One should, however, note that Finnish victory was close to becoming a complete defeat and, had the Russians known how exhausted their rivals were, had the Soviet delegation to the peace talks waited just a little more, then the total collapse of the Finnish army would have been revealed and no sisu spirit would have saved them from Stalin's cruel boots. It follows, then, that after looking at things from a wider perspective, we can see how national ethos proves, in the final analysis, to be a necessary condition for military victory but certainly not always a sufficient one.

\section{References}

Anderson, A. T. 1954. "Origins of the Winter War: A Study of
Russo-Finnish Diplomacy.” World Politics 6(2):169-189.

Anderson, B. 1983. Imagined Communities: Reflections on the Origin and Spread of Nationalism. New York, NY: Verso.

Barnard, F. M. 2003. Herder on Nationality, Humanity and History. Montreal and Kingston, Canada: McGill-Queen's University Press.

Bartov, O. 1991. Hitler's Army. New York, NY: Oxford University Press.

Becker, J. J. 1986. The Great War and the French People. London, UK: Berg Publishers.

Bergstrom, C. 2007. Barbarossa-The Air Battle: July-December 1941. London, UK: Chevron, Ian Allen.

Bloch, M. 1968. Strange Defeat: A Statement of Evidence Written in 1940. New York, NY; London, UK: W. W. Norton \& Co.

Browman, T. 2003. Irish Regiments in the Great War. Manchester, UK: Manchester University Press.

Chapman, G. 1968. Why France Collapsed. London, UK: Cassell.

Chew, A. F. 2002. The White Death: The Epic of the Soviet-Finnish Winter War. Michigan, IL: Michigan State University Press.

Churchill, W. 1948. The Second World War. Vol. 1. London, UK: Cassell.

Clausewitz, C. (1832) 1982. On War. London, UK: Penguin Books.

Cobban, A. 1990. A History of Modern France: Volume 3: 1871-1962. New York, NY: Penguin.

Derry, T. K. 1957. A Short History of Norway. London, UK: George Allen \& Unwin.

- 1973. A History of Modern Norway. London, UK: Oxford University Press.

Duara, P. 1995. Rescuing History From Nation: Questioning Narratives of Modern China. Chicago, IL: University of Chicago Press.

Durkheim, E. (1912) 1995. The Elementary Forms of Religious Life. New York, NY: The Free Press.

Edwards, R. 2008. The Winter War: Russia's Invasion of Finland 1939-1940. New York, NY: Pegasus Books.

Engle, E. and L. Paananen. 1973. The Winter War: The Soviet Attack on Finland, 1939-1940. Mechanisburg, PA: Stackpole Books.

Etzioni, A. 2009. "Minorities and the National Ethos.” Politics 29(2):100-110.

Fentress, J. and C. Wickham. 1992. Social Memory. Oxford, UK: Blackwell.

Glantz, D. M. 1998. Stumbling Colossus: The Red Army on the Eve of World War. Lawrence, KS: University Press of Kansas.

—. 2001. Barbarossa: Hitler's Invasion of Russia, 1941. Gloucestershire, UK: Tempus. 
Glantz, D. M. and J. M. House. 1995. When Titans Clashed: How the Red Army Stopped Hitler. Lawrence, KS: University Press of Kansas.

Goss, G. D. 2009. Sibelius: A Composer's Life and the Awakening of Finland. Chicago, IL: University of Chicago Press.

Gregory, A. 2008. The Last Great War: British Society at the First World War. Cambridge, UK: Cambridge University Press.

Halbwachs, M. (1951) 1992. On Collective Memory. Chicago, IL: University of Chicago Press.

Halmesvirta, A. 2009. "A Foreign Benefactor and a Domestic Liberator: The Cults of Lenin and Mannerheim in Finland.” Scandinavian Journal of History 34(4):414-432.

Heller, M. and A. M. Nekrich. 1986. Utopia in Power: The History of the Soviet Union From 1917 to the Present. New York, NY: Summit Books.

Hindus, M. 1943. Mother Russia. London, UK: Collins.

House, J. M. 2008. Why War? Why an Army? Westport, CT: Praeger Security International.

Huntford, R. 1999. The Last Place on Earth. New York, NY: The Modern Library.

Karsh, E. 1986. "Finland: Adaptation and Conflict." International Affairs 62(2):265-278.

Kirby, D. G. 1978. "Revolutionary Ferment in Finland and the Origins of the Civil War 1917-1918.” Scandinavian Economic History Review 26(1):15-35.

Larsen, K. 1948. A History of Norway. Princeton, NJ: Princeton University Press.

Levi-Strauss, C. 1979. Myth and Meaning. New York, NY: Shocken.

Lieberson, S. 1991. "Small N's and Big Conclusions: An Examination of the Reasoning in Comparative Studies Based on a Small Number of Cases.” Social Forces 70(2):307-320.

Luostarinen, H. 1989. “Finnish Russophobia.” Journal of Peace Research 26(2):123-137.

Manninen, O. 1978. "Red, White and blue in Finland, 1918: A Survey of Interpretations of the Civil War.” Scandinavian Journal of History 3(3):229-249.

Most, B. A. and H. Starr. 1980. "Diffusion, Reinforcement, Geopolitics, and the Spread of War." American Political Science Review 74(4):932-946.

Mueller, J. 1989. Retreat From Doomsday: The Obsolescence of Major War. New York, NY: Basic Books.

Olick, J. K. and D. Levy. 1997. "Collective Memory and Cultural Constraint: Holocaust Myth and Rationality in German Politics." The American Sociological Review 62(2):921-936.

Organski, A. F. K. and J. Kugler. 1977. "The Costs of Major Wars: The Phoenix Factor.” American Political Science
Review 71(4):1347-1366.

Paasivirta, J. 1981. Finland and Europe: The Period of Autonomy and the International Crises 1808-1914. Mineapolis, MN: University of Minnesota Press.

Przeworski, A. and H. Teune. 2000. The Logic of Comparative Social Inquiry. Malabar, FL: Krieger Publishing Company.

Raun, T. U. 1984. "The Revolution of 1905 in the Battle of Provinces and Finland.” Slavic Review 43(3):453-467.

Richardson, L. F. 1960. Arms and Insecurity. Chicago, IL: Quandrangle.

Rothstein, B. 2000. "Social Capital in the Social Democratic State: The Swedish Model and Civil Society." In The Decline of Social Capital? Political Culture as a Condition for Democracy, edited by R. Putnam. Princeton, NJ: Princeton University Press.

Rotundo, L. 1986. "The Creation of Soviet Reserves at the 1941 Campaign.” Military Affairs 50(1):21-28.

Russell, M. A. 2007. Between Tradition and Modernity: Aby Warburg and the Public Purposes of Art in Hamburg 1896-1918. New York, NY; Oxford, UK: Berghahn Books.

Scott, E. 1989. Australia During the War: The Official History of Australia in the War of 1914-1918. Brisbane, Australia: University of Queensland Press.

Screen, J. E. O. 2001. Mannerheim: The Finnish Years. London, UK: Hurst \& Co. Ltd.

Service, R. 2005. A History of Modern Russia From Nicholas II to Vladimir Putin. Cambridge, MA: Harvard University Press.

Shirer, W. L. 1969. The Collapse of the Third Republic: An Inquiry Into the Fall of France in 1940. New York, NY: Simon and Schuster.

Siaroff, A. 1999. "Democratic Breakdown and Democratic Stability: A Comparison of Interwar Estonia and Finland.” Canadian Journal of Political Science 32(1):103-124.

Silbey, D. 2005. The British Working Class and Enthusiasm for War, 1914-1916. New York, NY; London, UK: Frank Cass.

Simkins, P. 1998. Kitchener's Army: The Raising of the New Armies 1914-1916. Manchester, UK: Manchester University Press.

Slepyan, K. 2006. Stalin's Guerrillas: Soviet Partisans in World War II. Lawrence, KS: University Press of Kansas.

Smith A. 1986. The Ethnic Origins of Nations. Oxford, UK: Blackwell.

Spears, E. 1954. Assignment to Catastrophe. London, UK: William Heinmann Ltd.

Spring, D. W. 1986. "The Soviet Decision for War Against Finland, 30 November 1939.” Soviet Studies 38(2):207-226.

Toynbee, A. J. 1954. A Study of History. New York, NY: Oxford University Press.

Treadgold, D. W. 1995. Twentieth Century Russia. Boulder, CO: Westview Press. 
Trotter, W. 1991. A Frozen Hell: The Russo-Finnish Winter War of 1939-1940. Chapel Hill, NC: Algonquin Books.

Verhey, J. 2000. The Spirit of 1914: Militarism, Myth, and Mobilization in Germany. Cambridge, UK: Cambridge University Press.

Vital, D. 1971. The Survival of Small States: Studies in Small Power-Great Power Conflict. London, UK: Oxford University Press.

Waterfield, G. 1940. What Happened to France. London, UK: John Murray.

Weinberg, G. L. 1994. A World at Arms: A Global History of
World War II. New York, NY: Cambridge University Press. Wright, G. 1995. France in Modern Times. New York, NY: W. W. Norton \& Company.

\section{Bio}

Eyal Lewin, Ph.D., assistant professor, Department of Middle Eastern Studies and Political Science, Ariel University, Israel; research fields: national resilience, patriotism, national ethos, and civil religion. 